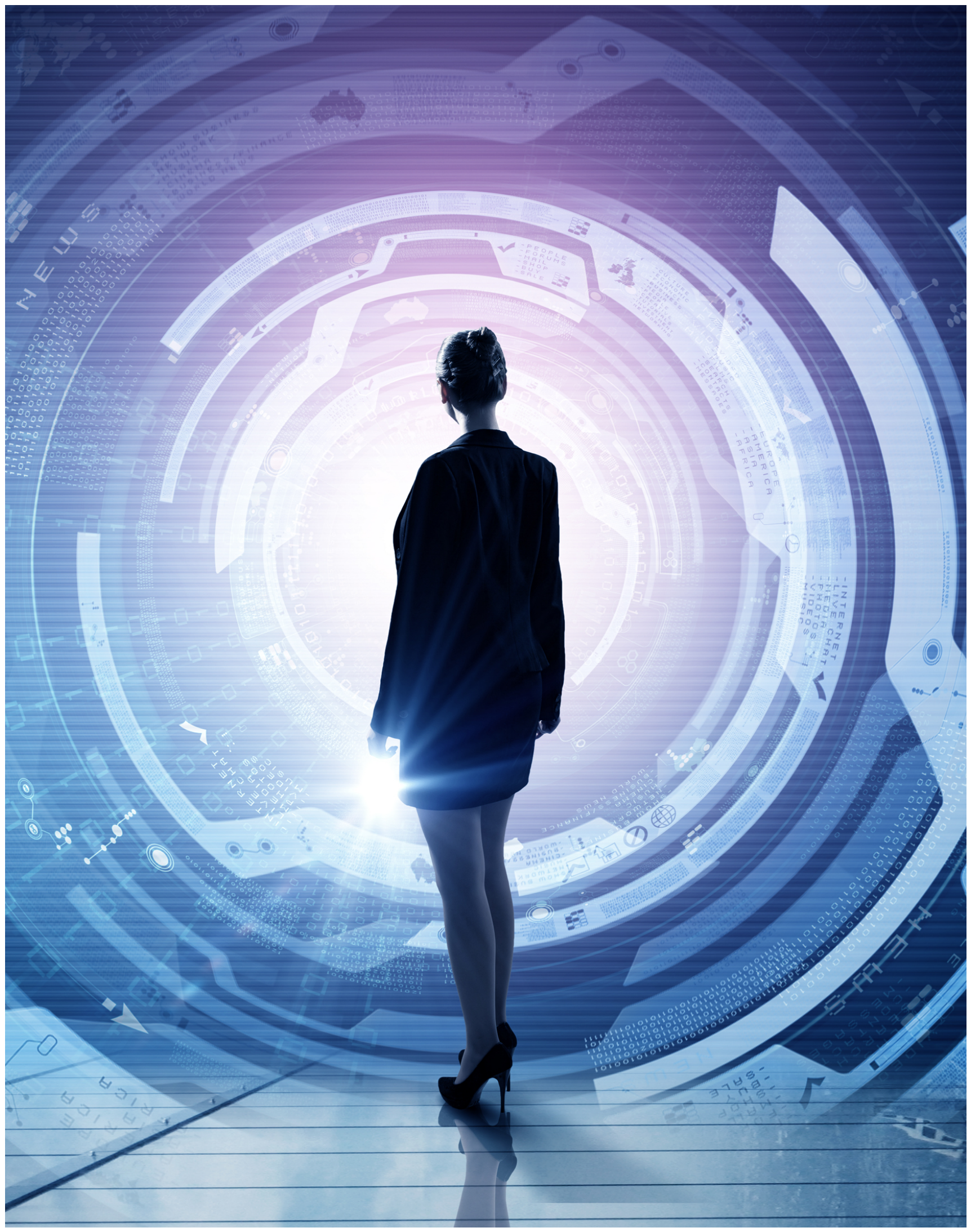




\section{O FUTURO QUE NOS ESPERA}

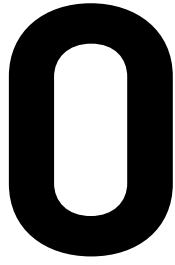

tempo circular, a repetição das estações e a inexistência do relógio organizaram a vida cotidiana até meados da Idade Média. Com o advento do relógio, que marcava apenas o horário das rezas nas grandes torres das igrejas, no território que chamamos hoje de Europa, a vida passou a ser organizada também por um tempo chamado linear, infinito. A incorporação do tempo do relógio na vida cotidiana levou vários séculos, e só recentemente o tempo mundial foi unificado, apesar de alguns países ainda guardarem temporalidades diferentes (como China e Israel). A noção de tempo, uma construção humana, passou a guiar a vida nas escolas, no trabalho, no lazer, no transporte, enfim, em todas as atividades do dia a dia.

Todavia, esse tempo linear transformou-se no tempo simultâneo dos computadores, que nos bombardeia com informações de toda ordem. Não é possível prever o que vai acontecer quando os humanos incorporarem o tempo simultâneo, mas já podemos sentir o sabor do futuro que nos espera. Milhões de dados podem ser acessados ao mesmo tempo, decisões precisam ser tomadas sem que se possa avaliar a totalidade das informações... Torna-se cada vez mais necessário desenvolver a capacidade de processar e de interpretar dados para decisões em tempo real.

Assim, a GV-executivo traz o debate contemporâneo sobre essa era dos dados, com foco em suas consequências para o mundo dos negócios. Agradecemos ao professor Eduardo Henrique Diniz, que conduziu a organização dos artigos que compõem este caderno especial e que tratam de alguns dos assuntos mais relevantes sobre a temática. João Luiz Becker e Eduardo Henrique Diniz discutem como disseminar a linguagem dos dados; Simone S. Luvizan debate a questão do reúso dos dados, ou seja, num ecossistema complexo, como os dados são utilizados para diferentes fins aos quais foram gerados, um problema atual que traz a necessidade de incluir procedimentos éticos no manuseio das informações. Em continuidade, Aron Belinky mostra que o big data ainda não foi incorporado nos indicadores de sustentabilidade; Silvia Rodrigues Follador e Julie Ricard tratam da utilização do big data para várias situações: mapeamento de pobreza, monitoramento de fluxos migratórios e planejamento de transportes, para o bem comum. $\mathrm{O}$ caderno especial traz ainda dois artigos sobre regulação dos dados: Maria Cecília Oliveira Gomes explora os novos direitos nesse campo, e Bruno Ricardo Bioni discute as leis de proteção de dados pessoais.

Completam a edição o artigo de Glessia Silva e Luiz Carlos Di Serio, que mostra que os programas de inovação brasileiros não são adequados às necessidades dos pequenos negócios nem ao desenvolvimento econômico, social e local do país; o texto de Viviane Monteiro, trazendo a interessante história da obsolescência planejada, que começou em 1924 com o cartel das produtoras de lâmpadas, e discutindo necessidades psicossociais de novos produtos; e o artigo de Felipe Bogéa, Eliane Zamith Brito e Lilian Carvalho sobre as incertezas que cercam o investimento e o controle do marketing nas redes sociais.

Apresentamos ainda as colunas Sociedade e Gestão, de Amon Narciso de Barros; Carreira, de Beatriz Maria Braga; e Economia, de Paulo Sandroni; além de uma entrevista com Rachel Maia, mulher negra que superou barreiras, esteve à frente de empresas do mercado de luxo como Pandora e Tiffany \& Co. no Brasil e hoje responde pela Lacoste no país.

Desejamos uma ótima leitura a todos.

Maria José Tonelli - Editora chefe

Adriana Wilner - Editora adjunta 